(C) В.В.Паржницький, 2012 ISSN 2076-8184. Інформаційні технології і засоби навчання. 2012. №4 (30). Режим доступу до журналу: http://www.journal.iitta.gov.ua

УДК 377.352

Паржницький Віктор Валентинович, кандидат педагогічних наук, начальник відділення науково-методичного забезпечення змісту професійно-технічної освіти Інституту інноваційних технологій і змісту освіти МОНмолодьспорту, м. Київ, е-mail: vvp5@meta.ua

\title{
ВИКОРИСТАННЯ СЕРВІСІВ ІНТЕРНЕТ ДЛЯ ПІДВИЩЕННЯ ЯКОСТІ ТЕОРЕТИЧНОГО І ВИРОБНИЧОГО НАВЧАННЯ В ЗАКЛАДАХ ПРОФЕСІЙНО-ТЕХНІЧНӦ̈ ОСВІТИ
}

\begin{abstract}
Анотація
Статтю присвячено аналізу сервісів Інтернет, які доцільно використовувати під час уроків теоретичного і виробничого навчання в закладах професійно-технічної освіти. Йдеться про електронні бібліотеки, професійні форуми, фахові інтернет- та відео- журнали, проведення вебінарів, а також соціальні сервери на яких міститься інформація за професійним спрямуванням, що уможливить поглиблення теоретичних і закріплення практичних знань учнів під час їхньої самостійної підготовки, підвищить ефективність теоретичного і виробничого навчання. Акцентується увага на дотриманні ергономіко-фізіологічних правил для ефективної та результативної роботи за комп'ютером учнів. Перспективним напрямом роботи $є$ використання сервісів Інтернет у контексті дистанційної освіти в закладах професійно-технічної освіти.
\end{abstract}

Ключові слова: професійне навчання, сервіси Інтернет, теоретичне i виробниче навчання.

Постановка проблеми. Докорінні зміни, що відбуваються в сучасних ринкових умовах українського суспільства висувають нові вимоги до рівня професійної підготовки кваліфікованих робітників. Зокрема актуальною є проблема підготовки конкурентоспроможних на вітчизняному i міжнародному ринках кваліфікованої праці робітничих кадрів, здатних застосовувати новітні технології і сировину, здійснювати новаторську діяльність, професійно самовдосконалюватися впродовж професійної кар'єри. Про це наголошується в Державній цільовій програмі розвитку професійно-технічної освіти на 2011-2015 рр. (2011), Проекті Національної 
стратегії розвитку освіти в Україні на 2012-2021 рр. (2011), відповідно до яких нагальною є впровадження у навчально-виробничий процес державних професійнотехнічних навчальних закладів інформаційно-комунікаційних технологій шляхом утворення електронних бібліотек, оснащення комп'ютерними комплексами тощо [1].

Отже, ми поставили за мету проаналізувати найефективніші сервіси Інтернет для підвищення якості теоретичного і виробничого навчання в закладах професійнотехнічної освіти.

Аналіз останніх досліджень і публікацій. Різні аспекти використання сервісів Інтернету в освітній процес вищих та професійно-технічних навчальних закладах висвітлено у наукових працях В.Ю. Бикова, О.Г. Глазунова, Н.В. Морзе, Т.В. Волкової, В.В. Осадчого та ін. Проте проблема використання сервісів Інтернет для підвищення якості теоретичного і виробничого навчання в закладах професійнотехнічної освіти ними не розглядалася, що й зумовило тему нашої публікації.

Як відомо, виробничі (професійні) уміння учнів передбачають знання та навички і формуються на грунті здобутих знань і здобутих навичок $[4,45] .3$ огляду на це важливе значення мають теоретичні знання, їх поглиблення та вдосконалення різними засобами, серед яких чільне місце посідають електронні бібліотеки, що являють собою розподілені інформаційні системи, які дозволяють зберігати i використовувати різнорідні колекції електронних документів (тексти, графіку, аудіо, відео тощо) завдяки глобальним мережам передачі даних в зручному для кінцевого користувача вигляді. Їх використання надасть можливість:

- реалізації випереджального навчання - організацію попереднього вивчення найскладнішого для учнів матеріалу заздалегідь до огляду його за навчальною програмою (пропедевтичне ознайомлення з поняттями майбутньої теми, опрацювання опорних понять тощо);

- виконання домашніх завдань у різних формах (самостійні роботи, доповіді, реферати тощо).

Цінними, на наше переконання, $є$ Інтернет сервіси, присвячені окремій професії, справі, виду діяльності. Найпоширенішими є «Клуби майстрів», «Школи крою та шиття», «Інтернет-журнали», «Майстерні» та інші види такі як: «Делай Сам.py - Интернет-журнал для самодельщиков»http://delaysam.ru/sadtech/sadtech4.html; «101 курс» - http://www.101course.ru/; «Школа 
шитья» - http://www.korfiati.ru/2009/02/kak-sshit-plate/). Позитивної оцінки заслуговує те, що на таких сайтах викладається документація письмового інструктування: інструкційні карти, інструкційно-технологічні карти, карти технологічного процесу, навчальні алгоритми, картки організації праці тощо. Як відомо, застосування окреслених видів документації письмового інструктування як системи сприяє розвитку навичок самостійної виробничої діяльності учнів, цілісному формуванню професійних знань, умінь і навичок.

Поширеними Інтернет сервісами $є$ різного виду професійні форуми, які доцільно використовувати учням під час самостійної підготовки, а також при підготовці до додаткових форм навчання: конференцій, олімпіад, тематичних вечорів тощо. Педагогічним працівникам слід заздалегідь добирати саме такі форуми на яких учням можна знайти відповіді на задані запитання, інформацію для поглиблення теоретичних знань, а також ті форуми на яких вони матимуть змогу осягнути секретами професійної майстерності, здійснити обмін досвідом роботи («Профессиональный форум ForumHouse» - http://www.forumhouse.ru/threads/13760/; «Форум Добромиль.org» - http://dobromyl.org/forum/index.php?topic).

Важливими для підвищення якості теоретичного і виробничого навчання учнів професійно-технічних навчальних закладів навчання $є$ сервіси, на яких містяться відеожурнали за професійною спрямованістю, що наочно демонструють:

- послідовність виконання трудових рухів;

- високопродуктивні методи і прийоми виробничої праці;

- правильність виконання роботи із дотриманням правил техніки безпеки тощо;

- виробничі умови тих чи інших підприємств (віртуальні виробничі екскурсії).

Окремі журнали містять інформацію щодо новинок матеріалів, сировини, інструменту, техніки тощо. Разом з тим, цінність таких відеожурналів полягає в тому, що відеоряд супроводжується інструктажем кваліфікованого робітника або кращого виробничника, детальними поясненнями, а також інформацією інструктивного характеру вказівками про послідовність, технологію виготовлення тощо. Завдяки таким відеожурналам майстер виробничого навчання разом з учнями має змогу здійснити добір кращих методів і прийомів організації виробництва, візуальне вивчення, спостереження; оформлення та узагальнення передового досвіду; визначити сфери розповсюдження, можливого застосування та впровадження 
передового виробничого досвіду у виробництво. Наприклад, найпоширенішими $є$ відеожурнали для будівельних спеціальностей такі як: «Wolf Group» (http://www.wolfgroupweb.com/); «KNAUF» (http://superpol.satx.ru/); «EXPRESS POL» (http://www.express-pol.ru/knauf1.html) та інші.

Великою групою засобів навчання є соціальні сервіси Інтернету, до яких включають [3]:

1) соціальні пошукові системи - системи, які дозволяють користувачам самим визначати, у якому напрямі вести пошук, які сайти переглядати насамперед, на які слова звертати першочергову увагу i як представляти знайдені результати (http://company.quintura.com/ru);

2) засоби для збереження закладок - он-лайн засоби для збереження посилань на веб-сторінки, що дозволяє додавати посилання 3 будь-якого комп'ютера, підключеного до мережі Інтернет; мати доступ до них з будь-якого комп'ютера, підключеного до мережі Інтернет; позначати закладкам теги (мітки-категорії), що згодом полегшує їх пошук (http://www.google.com/bookmarks);

3) соціальні сервіси збереження мультимедійних ресурсів - сервіси мережі Інтернет, які дозволяють безкоштовно зберігати, класифікувати, обмінюватися цифровими фотографіями (http://picasaweb.google.com), аудіо(http://www.podcaster.org.ua, http://rpod.ru) i відеозаписами (http://youtube.com), текстовими файлами (http://docs.google.com), презентаціями (http://www.slideshare.net), книгами (http://www.google.com/books, http://www.scribd.com), а також організовувати обговорення контенту тощо.

Таким чином, в контексті нашої проблеми соціальні сервіси Інтернету доцільно використовувати учням при самостійній підготовці до уроків теоретичного і виробничого навчання: при підготовці рефератів, доповідей, курсових робіт, у процесі виконання домашніх завдань тощо.

На нашу думку, важливим сервісом Інтернет для учнів професійно-технічних навчальних закладів $\epsilon$ сайт навчального закладу на якому висвітлено важливу інформацію щодо організації навчально-виробничого процесу, позанавчальної роботи, новинок навчального життя, важливих подій, посилання на сайти віртуальних бібліотек, навчальні ресурси тощо. 
Для обміну виробничим досвідом, поглиблення теоретичних і практичних знань, організації спілкування між географічно віддаленими користувачами в режимі реального часу доцільним є застосування вебінарів, що являють собою заходи, організований в Інтернеті/Інтранеті через програмне забезпечення, за допомогою якого здійснюється передача знань в інтерактивному режимі. Віртуальний клас працює в середовищі як Інтернету, так і Інтранету. Він об'єднує в єдиному інтерфейсі різні інструменти комунікації: текст, голос і відеочати, «білі дошки» для спільного малювання. Найбільш досконалі По-класи, на додаток до перерахованого, дають можливість демонструвати презентації PowerPoint, документи у форматах doc i pdf, електронні таблиці Excel, анімацію і відео. Крім того, з їх допомогою здійснюється показ веб-ресурсів, робочого столу або активних додатків з комп’ютера ведучого. Саме завдяки вебінарам можна організувати: майстер-класи за участю кращих вітчизняних й іноземних виробничників, які наочно продемонструють передові методи і прийоми виробничої праці, технологію виготовлення; вивчення і поширення виробничого досвіду - джерело підвищення продуктивності праці, впровадження нових форм організації праці.

Насамкінець зауважимо, що використання сервісів Інтернет під час самостійної підготовки учнів професійно-технічних навчальних закладів уможливлюється за умови дотримання важливих правил роботи з комп'ютером, оскільки відомо, що значне місце в ефективності і безпеці праці 3 комп’ютером має організація та облаштування робочого місця учня, що, на переконання науковців-ергономістів має відбуватися відповідно до таких правил:

1) очі мають бути на рівні верхньої частини екрана;

2) голова має бути прямою або ледь нахиленою вперед;

3) не повинно бути жодного нахилу голови або тулуба;

4) спина має бути ледь нахилена в протилежний від дисплея бік;

5) поперекова частина має бути ледь нахилена вперед;

6) верхня частина

руки має бути у вертикальному положенні;

7) лікті - під кутом 90\%;

8) передпліччя і руки мають бути горизонтальними;

9) стегна - горизонтально, коліна - під кутом 90\%; 
10) бажано мати підставку для ніг.

Окреслених вище правил доцільно дотримуватися для ефективної та результативної роботи за комп’ютером у разі довготривалої праці учнів [2].

Висновки. Результати нашого наукового пошуку дають підстави стверджувати, що комплексне застосування різних видів сервісів Інтернет у професійній підготовці учнів професійно-технічних навчальних закладів підвищать ефективність теоретичного і виробничого навчання, сприятимуть професійному вдосконаленню у подальшій професійній кар'єрі кваліфікованих робітників.

Проведене дослідження багатоаспектне і не вичерпується окресленою науковою розвідкою. Серед перспективних напрямів роботи виокремимо використання сервісів Інтернет у контексті дистанційної освіти в закладах професійно-технічної освіти.

\section{Список використаних джерел}

1. Державна цільова програма розвитку професійно-технічної освіти на 20112015 pp. : Постанова Кабінету Міністрів України від 13 квітня 2011 р. № 495 [Електронний ресурс]. - Режим доступу до документа : http://mon.gov.ua/index.php/ua/diyalnist/osvita/profesijno-tekhnichna/7576derzhavna-tsilova-programa-rozvitku-profesijno-tekhnichnoji-osviti-na-2011-2015roki - Мова укр.

2. Свтушенко Н.О. Аналіз варіативних ергономічних принципів при користуванні комп'ютера у вищому навчальному закладі / Свтушенко Н.О., Болгарін В.В. // Держава та регіони. Науково-виробничий журнал. - 2011. - №6. - С. 281-286.

3. Осадчий B.B. Сервіси Інтернет для дистанційного навчання у процесі професійної підготовки майбутніх учителів / В.В. Осадчий // Інформаційні технології і засоби навчання. - 2010. - №6 (20). Електронний ресурс. - Режим доступу до журналу: http://www.ime.edu-ua.net/em.html.

4. Професійна освіта : Словник : Навч. посіб. / Уклад. С.У. Гончаренко та ін.; За ред. Н.Г. Ничкало. - К. : Вища шк., 2000. - 380 с. 


\section{ИСПОЛЬЗОВАНИЕ СЕРВИСОВ ИНТЕРНЕТ ДЛЯ ПОВЫШЕНИЯ КАЧЕСТВА ТЕОРЕТИЧЕСКОГО И ПРОИЗВОДСТВЕННОГО ОБУЧЕНИЯ В УЧРЕЖДЕНИЯХ ПРОФЕССИОНАЛЬНО-ТЕХНИЧЕСКОГО ОБРАЗОВАНИЯ}

Паржницкий Виктор Валентинович, кандидат педагогических наук, начальник отделения научно-методического обеспечения содержания профессиональнотехнического образования Института инновационных технологий и содержания образования Министерства молодежи и спорта, г. Киев, e-mail: vvp5@meta.ua

\section{Аннотация}

Статья посвящена анализу сервисов Интернет, которые следует использовать во время уроков теоретического и производственного обучения в учреждениях профессионально-технического образования. Речь идет об электронных библиотеках, профессиональных форумах, специальных интернет- и видео- журналах, проведение вебинаров, а также социальных серверах, на которых содержится информация профессионального направления, которая поможет усовершенствованию теоретических и закреплению практических знаний учеников во время их самостоятельной подготовки, повысит эффективность теоретического и производственного обучения. Акцентируется внимание на выполнении эргономикофизиологических правил для успешной и результативной работы учеников за компьютером. Перспективным направлением работы является использование сервисов Интернет в контексте дистанционного образования в учреждениях профессионально-технического образования.

Ключевые слова: профессиональное обучение, сервисы Интернет, теоретическое и производственное обучение.

\section{USING OF THE INTERNET SERVICES FOR QUALITY INCREASE OF THEORETICAL AND INDUSTRIAL TRAINING AT VOCATIONAL EDUCATION INSTITUTIONS}

Victor V. Parzhnytsky, PhD (pedagogical sciences), head of the Department of guidance provision for vocational education content at the Institute of innovative technologies and education content of Ministry of Education, Science, Youth and Sports of Ukraine. Kyiv, email: vvp5@meta.ua 


\section{Resume}

The article is devoted to analysis of the Internet services that can be reasonably used during the lessons for theoretical and industrial training at vocational education institutions. The services include electronic libraries, professional forums, occupational Internet and video journals, holding of webinars, and public servers that contain information concerning vocational issues. All these can improve and strengthen theoretical and practical knowledge of students during their self-instruction, can increase efficiency of theoretical and industrial training. Attention is focused on ergonomics and physiological rules for effective and resulting work at students' computers. Prospective way of work here is using the internet services in a context of distance learning at vocational education institutions.

Keywords: vocational education, the Internet services, theoretical and industrial training. 